\title{
OPPORTUNITIES OF APLICATION OF A COMPETENCE-BASED APPROACH IN SOCIAL ADAPTATION OF MILITARIES DISCHARGED OF SERVICE
}

\author{
Venelin Terziev \\ Corresponding Member of the Russian Academy of Natural History, Moscow, Russia, Prof. D.Sc. \\ (Ec.), D.Sc. (National Security), D.Sc. (Social Activities), Ph.D., National Military University, Veliko \\ Tarnovo, Bulgaria; University of Rousse, Rousse, Bulgaria, terziev@skmat.com
}

\begin{abstract}
The process of social adaptation of discharged servicemen requires the application of integrated approaches embracing different aspects and elements. Current study presents a competence model for social adaptation of discharged servicemen in Bulgaria as an example. It provides important implications on the concept of competences acquiring and the application of lifelong learning. The model is built on the basis of identifying key competencies as a starting point in accordance to contemporary trends, social and educational policies. Thus it appears to be feasible and could be successfully developed and applied into the practice.
\end{abstract}

Keywords: social adaptation, social support, competence model.

\section{INTRODUCTION}

Dynamic changes of social environment, marked by positive and mostly negative effects of the factors on macro, and micro level and on the level of interpersonal relations in the course of social adaptation of the servicemen, discharged from military service, put on the agenda the need to seek suitable approaches for the formation of key competencies in them, based on which they could find their realization in the new conditions of life.

Placed too often against serious challenges, provoked by the change in the social status - professional, financial, value orientation, quality of life, etc., the alternatives for the servicemen, discharged from military service and the members of their families, are slow evolutionary changes or dynamic, sharp and short term revolutionary changes. Whichever alternative they might choose, the adaptability to the civil socium itself suggests the need for re-qualification, which is the basis of the social and occupational mobility of the servicemen, discharged from military service.

In solving the problems of concern, into account must be taken all objective factors relating to both the situation in the country and the global situation that is taking shape. And that means a comprehensive concept of development (reconstruction) of the Military Forces to be put in the basis of the continuing reform of the army, which to comprehensively develop the military doctrine, to take account of the new realities in 
the country and the world, and only then to draw routes to achievement of objectives and tasks, including channels and mechanisms for socio-professional mobility of the servicemen. Of course, the national policy on the management of human resources in the Bulgarian army should not deal mainly with the creation of social support systems for the discharged from military service servicemen. On the one hand, this is assumed, as otherwise people are deprived of their primary professional status, But on the other hand, the very treatment of the type of occupational activity as labor status in general, as a generic status, implies socio-occupational mobility. And from another point of view it cannot remain unnoticed what load the state takes, undertaking the provision of protection of the educated and labor capable population

The root of the problem lies in the fact that the state is far from the rational consideration of this aspect of its policy, which can be both fully expert and yet inadequate and inapplicable.

The process of socio-professional mobility is still going, develops chaotically, and there are all the signs of socio-professional mobility: change of occupation, transition from one socio-professional layer to another, but specific to the observed process of mobility of the servicemen are the following circumstances: massiveness, coercive nature and inadequate handling of the process, which is a reflection of inadequate national policy of the state in this regard. Here is missing the timeliness in considering the social base for the reform and the realistic deadlines for its implementation.

The negative consequences of all this, affect not only the families of the servicemen, but also the society as a whole and reflect like a boomerang on the image of the army itself. The main problem here becomes the sharpest contradiction between the need to build a professional army and the practically discredited profession of the serviceman as a result of events, reducing the reform in the army mainly to the mere reduction of its staff.

\section{THE PROBLEMS IN SOCIAL ADAPTATION OF DISCHARGED SERVICEMEN}

In their nature, these conflicts are related not only to the loss of permanent work. It is only natural for people to seek a profession which they can follow in their whole life. But there are also disappointments, and change, conversion of professions, which quite often occurs under duress. This conversion puts before them a lot of problems, the main of which are finding job and finding home. And in the absence of information in the conditions of a free labor market, for many, finding a new job is becoming a major problem. This is where lies the role of socio-psychological support, the core of which is the preparation, re-qualification, increase of qualification and settling in a new job. Moreover, in today's conditions of increasing need of the labor market for highly qualified specialists, education becomes a continuous and diverse process in terms of the technology of its acquiring. Not surprisingly, and quite naturally, in the recent years a variety of educational structures appeared, filling the gaps in our traditional, and in many ways conservative educational system.

For the discharged from and leaving the army servicemen this issue stays on the agenda for several reasons. First of all, here, more often it is not about continuing education in the context of its continuity, but about change of profession, although basic education and experience acquired over the years are essential. But the fact should not be overlooked that their civil profession is either "forgotten" or life already imposes new requirements on the professional competences acquired time ago in this profession.

Vital role plays the psychological factor, depending on which, the shift in the profession almost turns fate upside down. The main mechanism here should become a justified and really existing national military personnel policy, the core of which should be the preparation and job settling of the military staff during the time of their active service, and after their discharge. The role of education should be considered with respect to development of positive social and professional mobility. Positive social self-esteem and job satisfaction are subjective measures of positive socio professional mobility of the discharged from active service servicemen.

Another fundamental direction of the work is the development of legislative mechanisms, which to guarantee the right to education of the servicemen and proper conditions of life and work in the places of migration. Studies have shown that the education and job settlement of the servicemen are not expensive for the state by themselves. It is rather the so-called downward socio-occupational mobility, marked by a decline in the social status of servicemen, discharged from military service, in society, that turns out expensive. Therefore we adapted for the purposes of our study the methodology for sociological diagnosis of career development. The meaning of this methodology is in essence determining the orientation of the servicemen to one or another type of professional development.

And as the main values, obtained through their work are the professional-and life self-realization, and the life and social status (,costs” and „salary”), then the professional-and-life self-realization of the servicemen, discharged from military service, incorporates such summarized parameters, like professional achievements, 
needs and demands for professional knowledge and experience. The life and social status are described in the categories of professional development and career growth, social prestige of professional activity and financial security.

Key indicators, outlining comprehensively the sphere of professional and life goal setting and motivation to work, which should be set in such a methodology, are:

- Degree of creativity and initiative at work;

- Opportunity for application of the professional knowledge and competence;

- Opportunity for improvement of the professional experience;

- Satisfaction with the work done;

- Feeling real benefit from the work done;

- Autonomy in choosing solutions of work tasks;

- Work in strict accordance with the characteristics of the position;

- Opportunity for teaching others and transferring one's experiences to others;

- High appreciation of the results of professional activity on the part of colleagues and others;

- Participation in developing strategies for the organization's activity, development of long-term plans;

- Realization of professional experience;

- Leadership in the team;

- Opportunities for higher position, career development;

- High level of responsibility for the results of professional activity;

- High salary;

- Prestigious status in society;

- Better chances for career development;

- Prestige of work;

- Additional financial incentives;

- Good relationship with the direct superior;

- Good relationships in the team;

- Rhythm of work without strain and stress;

- Good workplace (office, equipment).

The applicability of the adapted for the purpose of increasing the efficiency of social adaptation of the servicemen, discharged from military service Methodology for Macro diagnostics of the Staff allows on the basis of one and the same set of indicators to determine the structure of the self-assessment of the opportunities and achievements in professional plan, and the life important perceptions related to the professional activity.

Socio-ontological basis of such an approach is the fact that through professional work, the serviceman, passing in the reserve, realizes his/her personal and professional potential, while assessing the significance of his/her work, will ensure his/her appropriate financial and social status in the society. Of course, for this purpose a set of indicators needs to exist, reflecting the whole complexity and depth of the participation of the individual in the professional activity, and the depth of the corresponding personal experiences.

The applicability of the Methodology for macro-diagnostics requires comparing in pairs of each of the given indicators. The technology of application of the methodology is the following: providing a list of beneficiaries in the form of cards, on each of which is entered a pair of indicators; in the diagnosis of attitudes, the overall task of working with the cards should be formulated in the form: „for each pair of statements, choose which one is most important for you in your work, to which one you would aspire most"; placing the card on the right or left, depending on whether the right or left statement is most important for the beneficent; entering the separated on the left cards in questionnaires. Processing the received data is possible through the application of the proper for the purpose methods of the factor and cluster analysis, as a result of which to 
get five typological groups of respondents, differing in their professional attitude in the sphere of professional activity.

This typology is obtained in the space of two factors: the goal setting factor, associated with the professional activity and the work motivation factor. The content of these factors and their respective weights are shown in Tables 1 and 2. High positive values for the goal setting factor, related to the work activity (level 0.5 and higher), correspond to the expressed attitudes and expectations towards the status of a military reservist (professional), to the professional growth and self-realization of the specialist. Low negative values for this factor $(-0.5$ or lower), reflect the attitude to the development of professionalism of administrative type, to hierarchical elevation in the career and the corresponding social status. Factor value of -0.5 to 0.5 corresponds to mixed, not rigidly delineated expectations and attitudes, and therefore, this space is not characterized by typology.

Table 1. Factor of professional and life goal setting

\begin{tabular}{|c|c|}
\hline Important for the respondents is ... & Factor weight \\
\hline 1. ...to bear high responsibility for the results of the professional activity & 0,642 \\
\hline 2. ...to show creativity and initiative in work & 0,067 \\
\hline 3. ...to see real benefit from the work done & 0,541 \\
\hline 4. ...to teach others and to transfer their experience to others & 0,522 \\
\hline 5. ...to be able to apply their knowledge in practice & 0,506 \\
\hline 6. ...to apply in practice their professional experience & 0,454 \\
\hline 7. ...to do the work in strict accordance with the instructions & 0,425 \\
\hline 8. ...to improve their professional experience & 0,425 \\
\hline 9. ...to hold a prestigious social status & $-0,768$ \\
\hline 10. ...to have good chances for career development & $-0,740$ \\
\hline 11. ...to hold higher position, to make a career & $-0,695$ \\
\hline 12. ...to have a prestigious job & $-0,691$ \\
\hline 13. ...to have a high salary & $-0,643$ \\
\hline 14. ...to have additional benefits & -0.474 \\
\hline
\end{tabular}

Table 2. Factor of motivation in the professional activity

\begin{tabular}{|l|c|}
\hline \multicolumn{1}{|c|}{ Important for the respondents is ... } & Factor weight \\
\hline 1. ...to form a strategy for the organization & 0,606 \\
\hline 2. ...to hold higher position, to make a career & 0,470 \\
\hline 3. ...to be leader in the team & 0,443 \\
\hline 4. ...to be independent in solving production tasks & 0,431 \\
\hline 5. ...to have good chances for career development & 0,367 \\
\hline 6....to have rhythmic work without strain and stress & -0.734 \\
\hline
\end{tabular}


IJASOS- International E-Journal of Advances in Social Sciences, Vol. IV, Issue 12, December 2018

\begin{tabular}{|l|c|}
\hline 7. ...to have good relationships in the team & -0.571 \\
\hline 8. ...to have a good workplace & -0.553 \\
\hline $9 . \ldots$ to have a good relationship with the manager & -0.503 \\
\hline 10. ...to receive bonuses & $-0,478$ \\
\hline $\begin{array}{l}11 . . . \text { to do their job in strict accordance with the requirements of the job } \\
\text { description }\end{array}$ & $-0,471$ \\
\hline
\end{tabular}

Thus, the applicability of the adapted methodology for macro-diagnostics makes it possible to assess the positive and negative effects of professional activity and the motivation of the military reservists in accordance with professional and social goal setting. This is one side of the social and professional mobility of the servicemen, discharged from military service. The other side is the place and role of military education in this mobility.

Account should be taken of the fact that to the problem of social protection of the servicemen, discharged from military service, their re-qualification and realization on the labor market, today is devoted considerable attention. Parallel to this, should not be underestimated the fact that the reported by the NSI (National Statistics Institute) and the Employment Agency (EA) data have shown little progress in this direction. This is evidenced by numerous publications in scientific journals, information collections, books, public media. To the problem of the social adaptation of the servicemen, discharged from or leaving the army, are dedicated scientific conferences, including international, many decisions and recommendations of these conferences. Of highersignificance between them are:

- The army was and remains not only a defender, having its place in the state system, but also its hostage. How the socio-political changes in the country affect and involve the army, we can see with our own eyes, and the modern world is very dynamic in this respect;

- The transition to a professional army makes the military service not so much a service, but a profession with the stemming from this law of the inevitable acceleration of the socio-professional mobility of the staff in the social division of labor. The military profession becomes an equal element in the professional structure of the society with its inclusion in the list of regulated professions. Therefore the professional education of the servicemen should become an element of the social technology of continuing education. This technology should provide opportunities for professional mobility of the servicemen both in its vertical and horizontal aspect.

\section{APPLICATION OF SOCIAL TECHNOLOGY IN THE PROCESS OF ADAPTATION}

In the broadest sense of the term the social technologies are certain components of human culture that arises evolutionary in the course of the historical process as a mechanism for satisfying specific historical needs. Arising spontaneously, social technologies have the ability to be built by the laws of the particular culture as an artificial formation, the main function of which is to achieve specific social goals. In this context, the profession is also a socio-technological mechanism that was conceived and developed within the social division of labor. Today, this social-technological mechanism represents a unity of scientific, educational and activity-practical processes, i.e. a complex social system. That determines the acceleration of the professional and the related to it social mobility of staff.

Account should be taken that profession „conquers the individual” through a whole range of socio-cultural phenomena. And here the most technological and mobile is the sphere of education: it is the education which is able to accumulate in itself the most valuable components of culture (including professional experience), using the tools of pedagogy to transform them for the purposes of adaptation, to the real cognitive and professional needs, to the abilities of the learners to consistently organize the process of active life and creative activity of man, to initiate and stimulate self-acquisition of new knowledge. Moreover, it comes to education, as the sole in its essence, sustainable enough technological sphere of formation of human personality, who not only adapts to the specific external environment, but is also able to transform it through his/her professional activities.

On the basis of what was said, the reform of the army as a professional institution, suggests also a reform of the relevant professional education, with a view to the new professional and educational realities. The main task in this direction is the creation of a system of continuing education in the field of military activity which would include pre-professional education, vocational education and further postprofessional education, 
which concerns the preparation and re-qualification of the discharged from active service, ensuring their inclusion in different spheres of civil professional activity.

Pre-professional military education as a component of the ongoing military education refers primarily to military education in schools, vocational schools, colleges, high schools and universities. Consideration should be taken that until recently in the school and university education initial military training was absent. Thus, the system of military pre-professional education has already been destroyed, and young people are unprepared in this respect - they do not even have access to such information. Moreover, in the quest of secondary and higher education to form knowledge about the most important spheres of public life: economic, social, legal, with the basics of health and labor safety, etc., military area was excluded from this list as an area in life and work of modern socium. Only in the last year, attempts were made to restore military education as a component of secondary and higher education and to return the military sphere back to the socium of today.

The problem in developing a system for continuous military education by no means applies to the task of militarization of education. It refers to solving the problem of its social comprehensiveness. This is extremely important in the context of the issues related to building a small, mobile, high technology and equipped with modern systems and weapons professional army, with clearly defined priorities and defense capabilities, adequate to the dynamic changes in the security environment and the growing resource deficit.

The vocational education continues to be a basic component in the system of continuous military education. In the course of the reform of the army, this system is also subject to change, which is by all means sufficiently effective and efficient, but at the cost of the discharge of thousands of competent servicemen in pursuit of their way to civil socium. And while the military education system is built on the integration of military and civil education, changes in the social environment determine the problem of updating the curricula of both areas of continuing education in accordance with the changes and requirements of the labor market. Solving this problem can be achieved with the participation of universities, including the military ones, in various sub-programs for grant assistance under the Human Resources Development operational program of the European Union, for introduction of new educational technologies, improvement of the management system of the universities for education and career development of military staff, updating of curricula in accordance with the labor market, and so on. It thus becomes possible to provide a reliable basis for the involvement of the servicemen, discharged from military service in civilian occupations with different depth of conversion of former military staff. This direction should be followed also by the post-professional education. It is one of the most important links in the system of continuing military education and a mechanism for social protection of the servicemen. The post-professional education system is a link in the social and professional mobility of the servicemen at the stage of transition from the sphere of military activities to civilian life. And particularly for that reason, its activities cannot begin with a class of already discharged military specialists.

Existing educational and qualification centers need to have information on the labor market in the regions concerned, to timely predict its dynamics and plan their activities accordingly. Thus, one of the most important mechanisms for the formation of a system of continuing military education is its diversification, consistent with the educational standards. The latter, in conditions of large-scale diversification of the education system, have the task to provide a single, common educational space and thus to protect learners from educational arbitrariness of individual institutions. In this direction acts the institution of the National Agency for Accreditation and Evaluation and accreditation of attractive and relevant to the new social conditions specialties in demand, in the field of security and defense, technical, economic, computer, social, etc. science, serving various spheres of public life. Increasingly sought and relevant are the new accredited specialties associated with the management of security and defense, protecting the population from disasters, accidents and catastrophes, protection of critical infrastructure, logistics, computer systems and technologies, administrative security, communication and information systems, and so on. And it is exactly the knowledge, skills and abilities of the servicemen in these areas that are appropriate to be used effectively in the period after their military service and passing into the civil socium.

It is on the basis of the integration between military and civil education, in compliance with the new social conditions, that further career of the servicemen, appropriate to their educational and professional orientation needs to be planned. It is necessary to form a system of continuous military education, starting from the early stages of service and ending with post-professional education of the active servicemen and the ones leaving the rows of the army. On this basis is being implemented the System for Managing Human Resources for Security and Defense, based on management by competence, which is one of the „big ideas ... along with management by objectives, and total quality management ... which has become a key strategy on human resources" (Terziev, 2017; Terziev, 2017a, pp.1375-1399; Terziev, 2017b, pp.1362-1377; Terziev, 
2017c, pp.1378-1392; Terziev, 2017d, pp.1352-1361; Terziev, 2017e, pp.914 - 922; Terziev, 2017f, pp. 923 935; Terziev, 2017g, pp.49-59; 9. Terziev, 2017h, pp.452-458; Terziev, 2017i, pp.786-796; Terziev, 2017j, pp. 997-1024; Terziev, Bogdanov, Madanski, Stefanov, 2017k, pp.85-97; Banabakova, Georgiev, 2017l, pp. 46-51; Banabakova, Georgiev, 2017m, pp. 462-467; Banabakova, Georgiev, 2017n, pp. 84-99; Banabakova, Georgiev, 2017o, pp. 468-483; Terziev, Madanski, Georgiev, 2017p, pp. 923-927; Terziev, Madanski, Georgiev, 2017q, pp. 1051-1055; Terziev, Nichev, Stoyanov, Georgiev, 2017r, pp. 888-892; Banabakova, Georgiev, 2017s, pp. 37-47).

\section{THE ESSENCE OF THE COMPETENCE MODEL PROPOSED}

Management by competence is the complex of knowledge, skills and behaviors corresponding to the security environment and the changes in the social environment, through which to reach a final result. This means „the introduction of key competences", by which "to specify the content and objectives of the educational process”, and the formation of "motivational, ethical, social and behavioral type” of staff. Through the competence approach it becomes possible to provide a competitive advantage of the capabilities of the servicemen, discharged from military service. Imperatives of this approach are: acquired knowledge, result of education of individuals; habits, formed as a result of professional experience and education; manner of communication, result of communication skills and team work. And that in itself means lifelong learning, consistent with the European Qualification Framework and the National Strategy Lifelong Learning. On this basis a competence model is created for increasing the efficiency of the process of social adaptation of the servicemen, discharged from military service.

People today live in a complex social and political world. More than ever, they want to plan their lives, to actively participate in society and to learn to adapt to any changes in everyday life. Lifelong learning in the broadest sense is the key to learning and understanding how to meet these challenges. Key competences for lifelong learning are a combination of knowledge, skills and attitudes that are crucial for human development, social inclusion, competitiveness and employability. They increase the opportunities of choice, improve adaptability to the changing conditions of life and work, make people social, mobile, competitive and motivated.

Key competences play an important role in empowering people vulnerable to unemployment and social exclusion. This is only half of the problem - these people have low levels of education, are of older age, or have "worthless" qualifications. In most countries in the European Union (EU) there are various training opportunities for those seeking knowledge with the necessary skills and qualifications. There are people trapped in a vicious circle of low education, poor self-esteem and low motivation for learning. They often do not seek knowledge and are doomed to poverty and social exclusion. Key competences are those, which can help them out of this circle and take advantage of available opportunities for learning and working. This model aims at empowering people at high risk of social exclusion (as in effect are the discharged from military service servicemen) by improving basic skills and thus building a road to sustainable income and meaningful life through lifelong learning. The direct beneficiaries of the model are defined at the beginning of this paper, while in general these are the servicemen discharged from military service and the members of their families. Indirectly, from the results of the project are expected to benefit the providers of adult education (centers for adult education, service training, initial and continuing vocational training, trainers, teachers and managers of educational institutions), as well as all institutions related to the provision of social services, services related to recruitment, etc.

In accordance with the European framework of the Member States we can define the following modules, relating to key competences: Module 1: Communication in mother tongue; Module 2: Communication in foreign languages; Module3: Mathematical skills and basic knowledge in science and technology; Module 4: Computer skills; Module 5: Learning to learn; Module 6: Social and civil competences; Module 7: Initiative and entrepreneurship; Module 8: Cultural knowledge.

Those key competencies are interdependent, and the emphasis in each particular case is based on critical thinking, creativity, initiative, problem/task solving, risk management and decision making. Each module covers a basic skill, provision of theory, concepts, practical examples, activities, useful links, guides, etc. Besides the acquisition of key skills by this risk group, the training provides a reference framework for support of the policy for education and training by the providers and employers, seeking to make lifelong learning widely available and open.

The work on key competences is linked to the European Qualifications Framework through a set of common principles and recommendations. On the basis of these recommendations of the Commission were defined eight key competences: communication in mother tongue, communication in a foreign language, basic competences in mathematics, science and technology, digital competence, learning to learn, interpersonal 
and civil competences, entrepreneurship and expression of culture.

These competences need to be acquired at the end of compulsory education and training and to be maintained by lifelong learning. These key competences are partly integrated into the common recommended levels and descriptors of the European Qualifications Framework (EQF). This especially refers to "learn how to learn”, "interpersonal and civil competences”, „entrepreneurship” and „cultural expressions”, included in the category „personal and professional competence”. Other key competences, such as foreign language skills, digital skills and math, science and technology, are formulated at a level that is more appropriate for the national and sectorial frameworks.

The development of the EQF, and especially the common recommended levels and descriptors, shows how the above key competences play an important role in all levels and areas of learning for the entire range of qualifications. Those key competencies represent a starting point in defining the mathematical formulation of the mathematical model for competence assessment for selection of a vacant job position as part of a program for social adaptation of the discharged from military service servicemen, developed in another work of ours. The establishment of the main key competencies that come at the output of the system, is related to assessment of the need for obtaining qualitatively new and different knowledge and skills and establishing their competitiveness on the primary labor market for participation in the selection foropen job positions (Terziev, Madanski, Georgiev, 2017t, pp. 748-753; Terziev, Madanski, Georgiev, 2017u, pp. 743-747; Madanski, Georgiev, 2017v, pp. 4-13; Madanski, Georgiev, 2017w, pp. 43-51; Terziev, Dzhumalieva, 2016a, s.233-253; Terziev, 2014, s.176-183; Terziev, 2014a, s.183-191; Terziev, 2014b, s.192-204; Terziev, 2014c, pp.194-201; Terziev, 2014d, s.201-210; Terziev, 2014e, s.210-222).

\section{CONCLUSION}

The main result of applying the proposed model is the creation of a specific methodology and didactic approaches to training in key competencies. This may include: a set of didactic training modules in eight key competences for lifelong learning, combined learning methodology, tools for internal and external evaluation of training, web portals and online training, tools for information exchange and dissemination of the results, news, links, and so on, as well as the innovative method of learning, addressing issues common to the majority of the targeted users. Among them are: insufficient education and learning motivation and lack of cognitive abilities. The methodology allows flexible learning in such a way that both young people and adults can start, interrupt and re-start their own career path in order to achieve improvement of studying process and career realization.

\section{REFERENCE LIST}

Terziev, Venelin. (2017). Opportunities for improving the efficiency of the socialadaptation of servicemen discharged from military service in Bulgaria. // Catalogue of the scientific, educational and methodical literature presented by authors at the I-XXXIV All-Russian book exhibitions held by Academy of Natural History, Exposition on the Frankfurter Buchmesse 2017, XXVII, Moskow, Academy of Natural History, 2017.

Terziev, Venelin. (2017a). Social adaptation as a social process in the adaptation of military personnel. // Journal of Economic Geography, International Health, Oxford University Press, 17, 2017, N 6(2), pp.1375-1399, ISSN 1468-2702.

Terziev, Venelin. (2017b). Insights into some examples of triggering the process of social adaptation. // International Health, Oxford University Press, 9, 2017, N6 (2), pp.1362-1377, ISSN 1876-3413.

Terziev, Venelin. (2017c). Examples of modelling social adaptation of servicemen discharged from military service. // International Health, Oxford University Press, 9, 2017, N 6 (2), pp.1378-1392, ISSN 18763413.

Terziev, Venelin. (2017d). Studying different aspects of social adaptation. // International Health, Oxford University Press, 9, 2017, N6 (2), pp.1352-1361, ISSN 1876-3413.

Terziev, Venelin. (2017e). Social adaptation and socialization as processes: characteristics, principles, factors. // European Journal of International Law, Oxford University Press, 28, 2017, N 4 (2), pp.914 922, ISSN 0938-5428. 
IJASOS- International E-Journal of Advances in Social Sciences, Vol. IV, Issue 12, December 2018

Terziev, Venelin. (2017f). Factors affecting the process of social adaptation. // European Journal of International Law, Oxford University Press, 28, 2017, N 4 (2), pp. 923 - 935, ISSN 0938-5428.

Terziev, Venelin. (2017g). A new view on social adaptation of the military, discharged from military service in Bulgaria. // IJASOS- International E-Journal of Advances in Social Sciences, April 2017, 3, 2017, N 7, ISSN 2411-183X, pp.49-59.

Terziev, Venelin. (2017h). Factors affecting the process of social adaptation. // 3rd International Conference on Advanced Research in Business and Social Sciences 2017 29th to 30th March, 2017, 1, 2017, ISBN: 978-967-13620-2-0, pp.452-458.

Terziev, Venelin. (2017i). A New View on Social Adaptation of the Military, Discharged From Military Service in Bulgaria. // Intcess 2017, 4th International conference on education and social sciences, 6-8 February, 2017 - Istanbul, Turkey, 2017, ISBN 978-605-64453-9-2, pp.786-796.

Terziev, Venelin. (2017j). A new view on social adaptation of the military, discharged from military service in Bulgaria. // Oxford Review of Economic policy, 33, 2017, N 4 (2), pp. 997-1024, ISSN 0266-903X.

Terziev, V., Bogdanov, P., Madanski, V., Stefanov, S. (2017k). Approaches to social adaptation of servicemen discharged of military service. // Eight international scientific conference Knowledge without borders, 8-10 април 2016 г., Банско, България. International Journal Scientific papers, 12, 2016, N 2, ISSN1857-92, pp.85-97.

Banabakova, V., Georgiev, M. (2017l). Military professional forming of the cadets at Vasil Levski National Military University. // IJAEDU- International E-Journal of Advances in Education, April 2018, Turkey, International Organization Center of Academic Research, www.ocerints.org, Istanbul, Turkey, 2018, pp. 46-51, 4, 2018, N 10, e-ISSN: 2411-1821.

Banabakova, V., Georgiev, M. (2017m). Military professional forming of the cadets at Vasil Levski National Military University. // Proceedings of INTCESS2018- 5th International Conference on Education and Social Sciences 5-7 February 2018- Istanbul, Turkey, International Organization Center of Academic Research, www.ocerints.org, Istanbul, Turkey, 2018, pp. 462-467, ISBN: 978-605-82433-2-3.

Banabakova, V., Georgiev, M. (2017n). The role of the Balanced Scorecard as a tool of strategic management and control. // IJAEDU- International E-Journal of Advances in Education, April 2018, International Organization Center of Academic Research, www.ocerints.org, Istanbul, Turkey, 2018, pp. 84-99, 4, 2018, N 10, e-ISSN: 2411-183X.

Banabakova, V., Georgiev, M. (20170). The role of the Balanced Scorecard as a tool of strategic management and control. // Proceedings of INTCESS2018-5th In-ternational Conference on Education and Social Sciences 5-7 February 2018- Istanbul, Turkey, International Organization Center of Academic Research, www.ocerints.org, Istanbul, Turkey, 2018, pp. 468-483, ISBN: 978-605-824332-3.

Terziev, V., Madanski, V., Georgiev, M. (2017p). Offset implementation impact on technology transfer in Bulgaria. // IJAEDU- International E-Journal of Advances in Education, International Organization Center of Academic Research, www.ocerint.org, 3, 2017, N 9, pp. 923-927, e-ISSN: 2411-18.

Terziev, V., Madanski, V., Georgiev, M. (2017q). Offset as an economic operation and a trade practice. // IJAEDU- International E-Journal of Advances in Education, International Organization Center of Academic Research, www.ocerint.org, 3, 2017, N 9, pp. 1051-1055, e-ISSN: 2411-18.

Terziev, V., Nichev, N., Stoyanov, E., Georgiev, M. (2017r). A general principle of the development process of Balanced scorecards as an instrument of control. // IJAEDU- International E-Journal of Advances in Education, International Organization Center of Academic Research, www.ocerint.org, 3, 2017, N 9, pp. 888-892, e-ISSN: 2411-18.

Banabakova, V., Georgiev, M. (2017s). Problems and perspectives in Military professional education and realization of cadets in Bulgaria. // Journal of Innovations and Sustainability, Innovations and Sustainability Academy. 3, 2017, N 4, pp. 37-47, ISSN 2367-8127 (CD-ROM), ISSN 2367-8151 (online).

Terziev, V., Madanski, V., Georgiev, M. (2017t). Offset as an economic operation and a trade practice. // Proceedings of ADVED 2017- 3rd International Conference on Advances in Education and Social Sciences 9-11 October 2017- Istanbul, Turkey. International Organization Center of Academic Research, www.ocerint.org, 2017, pp. 748-753, ISBN: 978-605-82433-0-9. 
Terziev, V., Madanski, V., Georgiev, M. (2017u). Offset implementation impact on technology transfer in Bulgaria. // Proceedings of ADVED 2017- 3rd International Conference on Advances in Education and Social Sciences 9-11 October 2017- Istanbul, Turkey .International Organization Center of Academic Research, www.ocerint.org, 2017, pp. 743-747, ISBN: 978-605-82433-0-9.

Madanski, V., Georgiev, M. (2017v). The offset as a specific sort of economic activity. // Scientific journal «Economics and finance». Academic publishing house of the Agricultural University, Priority research areas: Collection of scientific articles, 2017, pp. 4-13, ISBN 978-617-7214-53-2.

Madanski, V., Georgiev, M. (2017w). Study of the effect of offset implementation on technology transfer in the Republic of Bulgaria. // Scientific journal «Economics and finance». Academic publishing house of the Agricultural University, Priority research areas: Collection of scientific articles, 2017, pp. 43-51, ISBN 978-617-7214-53-2.

Terziev, V., Dzhumalieva, A. (2016a). Dostapnost do pazara na truda i sotsialna adaptatsiya na osvobodenite ot balgarskata armiya voennosluzheshti i chlenovete na tehnite semeystva. // XI Mezhdunarodnoy nauchnoy konferentsii „Innovatsii v tehnologiyah i obrazovanii", 18-19 Marta 2016 g., Kuzbasskiy gosudarstvennayy tehnicheskiy universitet im. T.F. Gorbacheva, Belovo, 4, 2016, ISBN 978-5-906888-04-4, s.233-253 (Терзиев, В., Джумалиева, А. Достъпност до пазара на труда и социална адаптация на освободените от българската армия военнослужещи и членовете на техните семейства. // XI Международной научной конференции „Инновации в технологиях и образовании", 18-19 Марта 2016 г., Кузбасский государственный технический университет им. Т.Ф. Горбачева, Белово, 4, 2016, ISBN 978-5-906888-04-4, с.233-253).

Terziev, Venelin. (2014). Possible aspects of occupational and psychological adaptation of the military, discharged from military service and their families to a new activity life cycle. // Mezhdunarodnaya nauchno-prakticheskaya konferentsiya „Nauka XXI veka: teoriya, praktika, perspektivay”, 6 lyunya 2014, Ufa, Rossiya, 2014, ISBN 978-5-906763-30-3, s.176-183 (Terziev, Venelin. Possible aspects of occupational and psychological adaptation of the military, discharged from military service and their families to a new activity life cycle. // Международная научно-практическая конфреренция „Наука XXI века: теория, практика, перспективы", 6 Июня 2014, Уфа, Россия, 2014, ISBN 978-5-90676330-3, c.176-183).

Terziev, Venelin. (2014a). Realities of implementing the social adaptation procees of military personnel, discharged form service in Bulgaria. // Mezhdunarodnaya nauchno-prakticheskaya konferentsiya „Nauka XXI veka: teoriya, praktika, perspektivay”, 6 Iyunya 2014, Ufa, Rossiya, 2014, ISBN 978-5906763-30-3, s.183-191 (Terziev, Venelin. Realities of implementing the social adaptation procees of military personnel, discharged form service in Bulgaria. // Международная научно-практическая конференция „Наука XXI века: теория, практика, перспективы”, 6 Июня 2014, Уфа, Россия, 2014, ISBN 978-5-906763-30-3, c.183-191).

Terziev, Venelin. (2014b). Bulgarian experience in the development of social adaptation of military personnel, discharged from military service and their families. // Mezhdunarodnaya nauchnoprakticheskaya konferentsiya "Nauka XXI veka: teoriya, praktika, perspektivay”, 27 lyunya 2014, Ufa, Rossiya, 2014, ISBN 978-5-906763-30-3, s.192-204 (Terziev, Venelin. Bulgarian experience in the development of social adaptation of military personnel, discharged from military service and their families. // Международная научно-практическая конференция „Наука XXI века: теория, практика, перспективы”, 27 Июня 2014, Уфа, Россия, 2014, ISBN 978-5-906763-30-3, с.192-204).

Terziev, Venelin. (2014c). Possible aspects of occupational and psyhological adaptation of the military, discharged from military service and their families to a new activity life cycle. // Международная научно-практическая конференция: 27 Июня 2014, „Наука и Современность”, Уфа, Россия, 2014, ISBN 978-5-906763-48-8, pp.194-201 (Terziev Venelin. Possible aspects of occupational and psyhological adaptation of the military, discharged from military service and their families to a new activity life cycle. // Mezhdunarodnaya nauchno-prakticheskaya konferentsiya: 27 lyunya 2014, „Nauka i Sovremennosty”, Ufa, Rossiya, 2014, ISBN 978-5-906763-48-8, pp.194-201).

Terziev, Venelin. (2014d). Realities of implementing the social adaptation process of military personnel, discharged from service in Bulgaria. // Международная научно-практическая конференция 27 Июня 2014, „Наука и Современность”, Уфра, Россия, 2014, ISBN 978-5-906763-48-8, с.201-210 (Terziev, Venelin. Realities of implementing the social adaptation process of military personnel, discharged from service in Bulgaria. // Международная научно-практическая конфреренция 27 Июня 2014, „Наука и Современность”, Уфра, Россия, 2014, ISBN 978-5-906763-48-8, с.201-210). 
IJASOS- International E-Journal of Advances in Social Sciences, Vol. IV, Issue 12, December 2018

Terziev, Venelin. (2014e). Bulgarian experience in the development of social adaptation of military personnel, discharged from military service and their families. // Mezhdunarodnaya nauchnoprakticheskaya konferentsiya 27 Iyunya 2014, „Nauka i Sovremennosty”, Ufa, Rossiya, 2014, ISBN 978-5-906763-48-8, s.210-222 (Terziev, Venelin. Bulgarian experience in the development of social adaptation of military personnel, discharged from military service and their families. // Международная научно-практическая конференция 27 Июня 2014, „Наука и Современность”, Уфа, Россия, 2014, ISBN 978-5-906763-48-8, с.210-222). 